University of Nebraska - Lincoln

DigitalCommons@University of Nebraska - Lincoln

USDA National Wildlife Research Center - Staff Publications
U.S. Department of Agriculture: Animal and Plant Health Inspection Service

February 2006

\title{
Height Distribution of Birds Recorded by Collisions with Civil
} Aircraft

Richard A. Dolbeer

United States Department of Agriculture, Wildlife Services

Follow this and additional works at: https://digitalcommons.unl.edu/icwdm_usdanwrc

Part of the Environmental Sciences Commons

Dolbeer, Richard A., "Height Distribution of Birds Recorded by Collisions with Civil Aircraft" (2006). USDA National Wildlife Research Center - Staff Publications. 500.

https://digitalcommons.unl.edu/icwdm_usdanwrc/500

This Article is brought to you for free and open access by the U.S. Department of Agriculture: Animal and Plant Health Inspection Service at DigitalCommons@University of Nebraska - Lincoln. It has been accepted for inclusion in USDA National Wildlife Research Center - Staff Publications by an authorized administrator of DigitalCommons@University of Nebraska - Lincoln. 


\title{
Height Distribution of Birds Recorded by Collisions with Civil Aircraft
}

\author{
RICHARD A. DOLBEER, ${ }^{1}$ United States Department of Agriculture, Wildlife Services, Sandusky, OH 44870, USA
}

\begin{abstract}
The National Wildlife Strike Database for Civil Aviation in the United States contained 38,961 reports of aircraft collisions with birds (bird strikes) from 1990-2004 in which the report indicated the height above ground level (AGL). I analyzed these strike reports to determine the distribution of all strikes and those strikes causing substantial damage to aircraft by height. For the $26 \%$ of strikes above 500 feet $(152 \mathrm{~m})$ AGL $(\mathrm{n}=10,143)$, a simple negative exponential model, with height as the independent variable, explained $99 \%$ of the variation in number of bird strikes per 1,000-foot (305-m) interval. Strikes declined consistently by $32 \%$ every 1,000 feet from 501-20,500 feet (153-6,248 m). For strikes at $\leq 500$ feet, passerines, gulls and terns, pigeons and doves, and raptors were the identified species groups most frequently struck. For strikes at $>500$ feet, waterfowl, gulls and terns, passerines, and vultures were the species groups most frequently struck. For strikes that resulted in substantial damage to the aircraft, $66 \%$ occurred at $\leq 500$ feet, 29\% between 501-3,500 feet (153-1,067 m), and 5\% above 3,500 feet. A higher $(\mathrm{P}<0.001)$ proportion of strikes between 501-3,500 feet caused substantial damage to the aircraft (6.0\%) than did strikes at $\leq 500$ feet $(3.6 \%)$ or at $>3,500$ feet $(3.2 \%)$. For strikes at $\leq 500$ feet, July-October were the months with the greatest proportion of strikes relative to aircraft movements. For strikes at $>500$ feet, September-November and April-May had more strikes than expected. About $61 \%$ of the reported strikes above 500 feet occurred at night, compared to only $18 \%$ of civil aircraft movements. Thus, about 7 times more strikes occurred per aircraft movement at night compared to day above 500 feet. This analysis confirmed that management programs to reduce strikes should focus on the airport environment because $74 \%$ of all strikes and $66 \%$ of strikes causing substantial damage occur at $\leq 500$ feet. To minimize significant strike events occurring outside the airport ( $>500$ feet), efforts to predict or monitor bird movements using bird avoidance models and bird-detecting radar need to focus on heights between 500 and 3,500 feet AGL, with special emphasis on night movements of birds during April-May and September-November. (JOURNAL OF WILDLIFE MANAGEMENT 70(5):1345-1350; 2006)
\end{abstract}

\section{Key words}

aircraft, airport, bird, bird strike, civil aviation, damage, height, migration, nocturnal, waterfowl.

Aircraft collisions with birds and other wildlife (wildlife strikes) are an increasingly serious economic and safety problem, related in part to increasing populations of various large-bird species (e.g., Canada geese [Branta canadensis], Dolbeer and Eschenfelder 2002). Cleary et al. (2005) estimated wildlife strikes ( $98 \%$ involving birds) cost the civil aviation industry in the United States about $\$ 500$ million per year from 1990-2004. Allan and Orosz (2001) estimated that bird strikes annually cost commercial air carriers over US $\$ 1.2$ billion worldwide from 1999-2000. Bird strikes with civil and military aircraft from 1988-2005 killed at least 192 people and destroyed 144 aircraft (Richardson and West 2000, Thorpe 2003, Thorpe 2005, R. A. Dolbeer, United States Department of Agriculture, unpublished data).

The Federal Aviation Administration (FAA) has a standard form (5200-7) for the voluntary reporting of bird and other wildlife strikes with civil aircraft in the United States. The FAA has entered strike reports into a national database since 1990. Management programs to reduce bird strikes have focused on dispersing birds from the airport environment (Cleary and Dolbeer 2005) because over 70\% of wildlife strikes in the database occur below a height of 500 feet $(152 \mathrm{~m})$ above ground level (AGL; Cleary et al. 2005). I consider the airport environment to encompass an area out to 10,000 feet $(3,048 \mathrm{~m})$ from the runway, which is

${ }^{1}$ E-mail: Richard.a.dolbeer@aphis.usda.gov the distance where aircraft on approach typically descend below 500 feet AGL. The FAA-recommended restrictions on land uses that attract birds (e.g., landfills) extend to a distance of 10,000 feet from runways for airports servicing turbine-powered aircraft (Cleary and Dolbeer 2005).

However, there have been bird strikes reported at heights up to 32,000 feet $(9,754 \mathrm{~m})$ in the United States (Cleary et al. 2005) and 37,000 feet $(11,278 \mathrm{~m})$ in Africa (Laybourne 1974). My objective was to examine bird-strike reports for civil aircraft in the United States to determine the distribution of strikes by height (AGL) in relation to season of year and time of day (daylight vs. dark). This analysis may prove useful to ornithologists interested in the height distribution of migrating and soaring birds and to people in the aviation industry and wildlife management profession attempting to reduce the probability of bird strikes in the airport environment and off-airports at heights above 500 feet.

\section{Methods}

I used data from the FAA's National Wildlife Strike Database for Civil Aviation (Cleary et al. 2005). I used strike reports from January 1990-December 2004, excluding strikes with nonbird species and bird strikes without a reported height.

To examine the relationship between height above 500 feet and number of strikes, I grouped the number of strikes into 20 1,000-foot (304-m) intervals from 501-1,500 feet 
(153-457 m, interval 1 with a mean height of 1,000 feet [304 m]) to 19,501-20,500 feet $(5,944-6,248 \mathrm{~m}$, interval 20 with a mean height of 20,000 feet [6,096 m]). I used 1,000foot increments centered on 1,000-foot intervals because outside the airport environment, pilots often report strikes to the nearest 1,000 -foot interval. Using height interval as the single independent variable and number of reported strikes per interval as the dependent variable, I determined the equation that gave the best correlation (Statistix 2003).

To determine if strikes at certain height bands were more hazardous to aircraft than at others, I used Chi square analysis (Statistix 2003) to test the null hypothesis that the proportion of reported strikes causing substantial damage to the aircraft did not differ among height bands from 0-500 feet, 501-3,500 feet (153-1,067 m), and above 3,500 feet. The FAA classified bird-strike-related damage as substantial when the aircraft was destroyed or incurred damage or structural failure that adversely affected the structural strength, performance, or flight characteristics of the aircraft and that normally required major repair or replacement of the affected component (International Civil Aviation Organization 1989, Cleary et al. 2005).

To determine if the frequency of all strikes varied throughout the year for strikes above and below 500 feet, I used a Multinomial test (Statistix 2003) to test the null hypothesis that the monthly proportion of reported strikes and strikes causing substantial damage did not differ from the monthly proportion of aircraft movements by commercial air carriers, 1990-2004 (FAA 2005).

To determine if the frequency of strikes differed between night and day for strikes above and below 500 feet, I used a Multinomial test to test the null hypothesis that the proportion of reported strikes during night and day (one- half hour before sunrise to one-half hour after sunset) did not differ from the proportion of aircraft movements during night and day, 1990-2004. I used the number of aircraft movements during night and day for itinerant (i.e., nonlocal) air traffic at all Canadian airports below $60^{\circ}$ latitude, 1995-2003 (M. Villeneuve, Aviation Statistics, Transport Canada, unpublished data). Data for the proportion of night and day movements in the United States mimic the data for Canada, but were not available (E. C. Cleary, FAA, personal communication).

\section{Results}

From 1990-2004, there were 38,961 reported bird strikes in which the height was provided; $74 \%$ of these strikes occurred within 500 feet of the ground, 19\% from 5013,500 feet, and $7 \%$ above 3,500 feet (Table 1 ). Fifty percent $(14,375)$ of the strikes at $\leq 500$ feet, $27 \%(2,021)$ of the strikes from 501-3,500 feet, and 12\% (331) of the strikes above 3,500 feet identified the species or species group involved. For strikes at $\leq 500$ feet, passerines, gulls and terns, pigeons and doves, waterfowl, and birds of prey were the species groups most frequently struck. For strikes above 500 feet, waterfowl, gulls and terns, passerines, birds of prey, and vultures were the species groups most frequently struck. Waterfowl comprised $53 \%$ of the identified birds struck above 3,500 feet.

\section{Height Distribution of Strikes Above 500 Feet}

For the $26 \%$ of strikes occurring above 500 feet, a negative exponential model with height as the independent variable explained $99 \%$ of the variation in number of bird strikes per 1,000-foot interval (Fig. 1). The number of strikes declined consistently by $32 \%$ every 1,000 feet from $501-20,500$ feet.

Table 1. Species groups of birds reported as struck by civil aircraft in the United States at heights $\leq 500$ (152 m), 501-3,500 (153-1,067 $\mathrm{m})$, and $>3,500$ feet above ground level (AGL), 1990-2004.

\begin{tabular}{|c|c|c|c|c|}
\hline \multirow[b]{2}{*}{ Species group } & \multicolumn{3}{|c|}{ Height (feet) AGL } & \multirow[b]{2}{*}{ Total } \\
\hline & $0-500$ & $501-3,500$ & $>3,500$ & \\
\hline Passerines (Passeriformes) & 4,317 & 357 & 55 & 4,729 \\
\hline Gulls/terns (Laridae) & 4,062 & 471 & 49 & 4,582 \\
\hline Pigeons/doves (Columbidae) & 1,962 & 70 & 5 & 2,037 \\
\hline Waterfowl (Anatidae) & 1,160 & 656 & 177 & 1,993 \\
\hline Hawks/eagles/kites (Accipitridae) & 1,247 & 169 & 20 & 1,436 \\
\hline Shorebirds (Charadriiformes) & 555 & 11 & 7 & 573 \\
\hline Herons/egrets/bitterns/storks (Ciconiiformes) & 362 & 27 & 2 & 391 \\
\hline Vultures (Cathartidae) & 162 & 194 & 11 & 367 \\
\hline Owls (Strigiformes) & 281 & 10 & 2 & 293 \\
\hline Grouse (Tetraonidae) & 98 & 1 & 0 & 99 \\
\hline Cranes (Gruidae) & 47 & 8 & 0 & 55 \\
\hline Nighthawks/swifts (Caprimulgidae/Apodidae) & 44 & 8 & 1 & 53 \\
\hline Pelicans (Pelecanidae) & 22 & 8 & 1 & 31 \\
\hline Cormorants (Phalacrocoradicae) & 15 & 9 & 1 & 25 \\
\hline Albatrosses (Diomedeidae) & 14 & 0 & 0 & 14 \\
\hline Rails/coots (Rallidae) & 7 & 4 & 0 & 11 \\
\hline Loons/grebes (Gaviidae/Podicipedidae) & 3 & 7 & 0 & 10 \\
\hline Miscellaneous birds & 17 & 11 & 0 & 28 \\
\hline Total known birds & 14,375 & 2,021 & 331 & 16,727 \\
\hline Total unidentified birds & 14,431 & 5,448 & 2,355 & 22,234 \\
\hline Total birds & 28,806 & 7,469 & 2,686 & 38,961 \\
\hline
\end{tabular}




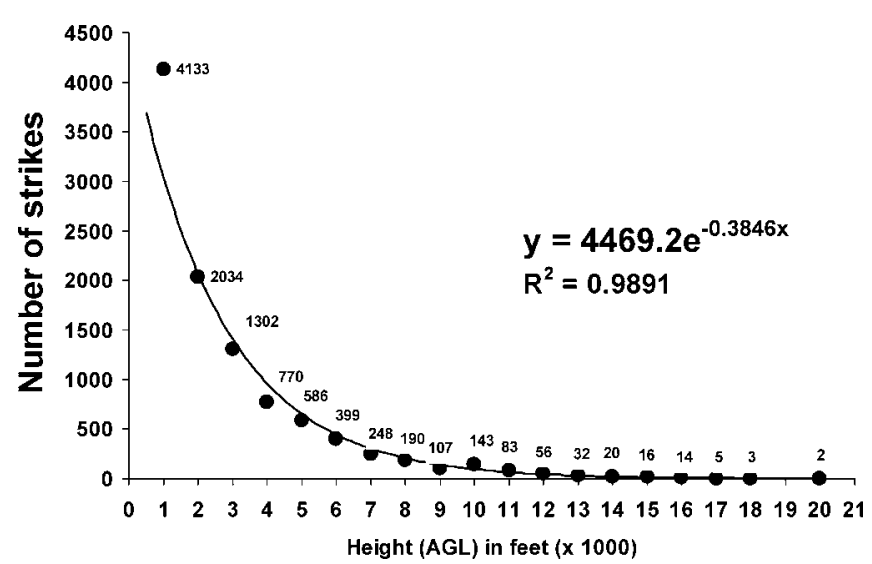

Figure 1. Number of reported bird strikes with civil aircraft in the United States from 1990-2004 as a function of 20 1,000-foot (305-m) height intervals from 501-1,500 feet (153-457 m, interval 1) to 19,501-20,500 feet $(5,944-6,248 \mathrm{~m}$, interval 20) above ground level $(n=10,143$ strikes). The number of reported strikes declined consistently by $32 \%$ for each 1,000-foot gain in height. There were 28,806 strikes reported from 0-500 feet (152 m) and 12 strikes reported from 20,501-32,500 feet $(6,249-9,906 \mathrm{~m})$ not included in this analysis.

Thus, whereas $74 \%$ of the total reported strikes occurred at $\leq 500$ feet, $19 \%$ occurred between 501-3,500 feet and only $7 \%$ occurred above 3,500 feet (Table 2).

\section{Proportion of Strikes Causing Substantial Damage by Height Band}

Whereas $26 \%$ of all strikes occurred above 500 feet, $34 \%$ of all strikes causing substantial damage occurred above 500 feet. A higher $(P<0.001)$ proportion of strikes between 501-3,500 feet caused substantial damage to the aircraft $(6.0 \%)$ than did strikes at $\leq 500$ feet $(3.6 \%)$ or at $>3,500$ feet $(3.2 \%$; Table 2$)$.

\section{Proportion of Strikes by Month}

For both strikes above and below 500 feet, the proportion of strikes occurring each month was different $(P<0.001)$ than expected based on the proportion of aircraft movements during those months (Table 3). For strikes at $\leq 500$ feet, July-October were the months with the greatest proportion of strikes; August was the peak month. The months December-April had fewer strikes than expected. For strikes at $>500$ feet, September-November and AprilMay had more strikes than expected and DecemberFebruary and June-July had fewer than expected.

\section{Proportion of Strikes by Day and Night}

Overall, there were about 2.5 times more strikes reported during daylight hours than at night (Table 4). However, because an estimated 4.5 times more aircraft movements occurred during day than at night, about 1.8 times more strikes per aircraft movement occurred at night than in the day $(P<0.001)$. This overall higher strike rate at night was due to the pronounced proportion of strikes above 500 feet occurring at night. About $61 \%$ of the reported strikes above 500 feet occurred at night compared to $18 \%$ of aircraft movements $(P<0.001)$. In contrast, proportionally fewer strikes occurred at $\leq 500$ feet at night $(16 \%)$, compared to the $18 \%$ of aircraft movements at night $(P<0.001)$. Above 500 feet, about 7 times more strikes occurred per aircraft movement at night compared to day (Table 4).

\section{Discussion}

My analysis confirmed (Dolbeer et al. 2000, MacKinnon 2002) that management programs to reduce bird strikes with civil aircraft should focus on the airport environment because $74 \%$ of all strikes and $66 \%$ of strikes causing substantial damage to aircraft occurred at $\leq 500$ feet. An analysis of data on the 25 large-transport aircraft $(>5,700$ $\mathrm{kg}$ takeoff weight) crashes caused by bird strikes worldwide since 1960 also supported these findings (Richardson and West 2000, Thorpe 2003, 2005). Bird strikes occurred at $<500$ feet in 23 of the $25(92 \%)$ accidents.

The months of July-October, especially August, were the months with the highest strike rates below 500 feet. With the addition of large numbers of recently fledged birds, populations of most bird species in North America are at their highest levels in late summer (Dolbeer 1998). In addition, these young birds are less adept than older birds at avoiding aircraft (Burger 1985, Kelly et al. 2001). During this pre-autumn-migration period, most strikes $(84 \%)$ at $\leq 500$ feet occurred during the day, probably when birds were undertaking localized movements for foraging and roosting.

Aircraft during climb and descent provide a unique method of sampling bird numbers at heights above 500 feet that lack the influence of bird-management actions on the ground at airports (Cleary and Dolbeer 2005). Above 500 feet, strikes declined exponentially by a remarkably consistent $32 \%$ per 1,000 -foot interval up to 20,500 feet. The fact that the numbers of strikes reported independently by thousands of pilots over a 15 -year period generated such

Table 2. Proportion of bird strikes with civil aircraft in the United States causing substantial damage at heights $\leq 500$ (152), 501-3,500 (153-1,067), and >3,500 feet (1,067 m) above ground level (AGL), 1990-2004.

\begin{tabular}{|c|c|c|c|c|c|}
\hline \multirow{2}{*}{$\begin{array}{l}\text { Height of } \\
\text { aircraft } \\
\text { (feet AGL) }\end{array}$} & \multicolumn{2}{|c|}{ All reported strikes } & \multicolumn{2}{|c|}{ Reported strikes with substantial damage } & \multirow{2}{*}{$\begin{array}{c}\% \text { of strikes } \\
\text { causing substantial } \\
\text { damage }^{\mathrm{a}}\end{array}$} \\
\hline & No. & $\%$ of total & No. ${ }^{a}$ & $\%$ of total & \\
\hline $0-500$ & 28,806 & 74 & 1,023 & 66 & 3.6 \\
\hline $501-3,500$ & 7,469 & 19 & 445 & 29 & 6.0 \\
\hline$>3,500$ & 2,686 & 7 & 85 & 5 & 3.2 \\
\hline Total & 38,961 & 100 & 1,553 & 100 & 4.0 \\
\hline
\end{tabular}

${ }^{a}$ The proportion of strikes and strikes causing substantial damage differed $\left(P<0.001, \chi^{2}=94.9,2 \mathrm{df}\right)$ among height bands. 
Table 3. Percent of strikes to civil aircraft in the United States occurring at $\leq 500$ and $>500$ feet $(152 \mathrm{~m})$ above ground level by month and the ratio of these percentages to the percent of aircraft movements each month, 1990-2004.

\begin{tabular}{|c|c|c|c|c|c|}
\hline \multirow[b]{2}{*}{ Month } & \multicolumn{3}{|c|}{$\%$ of total } & \multicolumn{2}{|c|}{ Ratio: $\%$ of all strikes $/ \%$ of movements } \\
\hline & Aircraft movements ${ }^{a}$ & Strikes $\leq \mathbf{5 0 0}$ feet $^{\mathrm{b}}$ & Strikes $>500$ feet $^{c}$ & $\leq \mathbf{5 0 0}$ feet & $>500$ feet \\
\hline Jan & 8.04 & 4.33 & 2.88 & 0.54 & 0.36 \\
\hline Feb & 7.52 & 3.71 & 3.25 & 0.49 & 0.43 \\
\hline Mar & 8.43 & 4.86 & 6.48 & 0.58 & 0.77 \\
\hline Apr & 8.22 & 5.86 & 9.22 & 0.71 & 1.12 \\
\hline May & 8.49 & 8.23 & 11.40 & 0.97 & 1.34 \\
\hline Jun & 8.47 & 9.05 & 4.01 & 1.07 & 0.47 \\
\hline Jul & 8.77 & 13.33 & 4.76 & 1.52 & 0.54 \\
\hline Aug & 8.92 & 15.50 & 8.63 & 1.74 & 0.97 \\
\hline Sep & 8.22 & 12.43 & 16.64 & 1.51 & 2.02 \\
\hline Oct & 8.59 & 10.42 & 19.19 & 1.21 & 2.23 \\
\hline Nov & 8.05 & 7.44 & 9.72 & 0.92 & 1.21 \\
\hline Dec & 8.28 & 4.85 & 3.83 & 0.59 & 0.46 \\
\hline Total & $359,315,179$ & 28,806 & 10,155 & & \\
\hline
\end{tabular}

${ }^{a}$ Based on total number of aircraft movements by month for commercial aircraft in the United States, $1990-2004$ (Federal Aviation Administration 2005).

${ }^{b}$ The proportion of strikes at $\leq 500$ feet occurring each month was different $\left(\chi^{2}=4,932,11 \mathrm{df}, P<0.001\right)$ than expected based on the proportion of movements each month.

c The proportion of strikes at $>500$ feet occurring each month was different $\left(\chi^{2}=3,653,11 \mathrm{df}, P<0.001\right)$ than expected based on the proportion of movements each month.

${ }^{d}$ Ratios above and below 1.0 indicate that the number of strikes occurring that month were greater or lesser than expected, respectively, than would have occurred if the proportion of aircraft-striking birds was equal to the proportion of aircraft movements.

a consistent exponential decay in relation to height suggests that the mean height distribution of birds above 500 feet has a fundamental relationship to some physical parameter, perhaps air density or energy expenditure to gain height.

Although some birds occasionally migrate at or soar to extreme heights of $>20,000$ feet (Alerstam 1990), I found that $93 \%$ of the strikes (and presumably birds) were below 3,500 feet. Only $5 \%$ of the reported strikes causing substantial damage to aircraft occurred from 3,500 feet up to 32,500 feet $(9,906 \mathrm{~m})$, compared to $29 \%$ between 501 and 3,500 feet and $66 \%$ at or below 500 feet. Bellrose (1971) documented heights of nocturnally migrating birds from a small airplane and found a similar pattern. Bellrose (1971) determined that the location of the majority of birds was between 500-1,000 feet, with numbers rapidly dropping off to almost 0 by 5,000 feet $(1,524 \mathrm{~m})$.

Above 500 feet, the peak months of strikes were AprilMay and September-November, which differed from the seasonal pattern below 500 feet. These spring and autumn months coincide with peak migration periods when birds are more likely to be flying at heights above 500 feet (Bellrose 1971, Alerstam 1990, Gauthreaux and Belser 2003). Because many birds migrate at night (Bellrose 1971, Gauthreaux and Belser 2003), this also helps explain the increased nocturnal strike rate above 500 feet compared to $<500$ feet.

To assist pilots in avoiding birds and significant strike events at heights above 500 feet (i.e., outside the airport environment), researchers have undertaken efforts to predict

Table 4. Percent of strikes to civil aircraft in the United States occurring at $\leq 500$ and $>500$ feet (152 m) above ground level during night and day (one-half hour before sunrise to one-half hour after sunset), 1990-2004, and the ratio of these percentages to the percentage of aircraft movements during night and day.

\begin{tabular}{|c|c|c|c|c|c|c|c|}
\hline \multirow[b]{2}{*}{ Time } & \multicolumn{4}{|c|}{$\%$ of total } & \multicolumn{3}{|c|}{ Ratio: $\%$ of strikes $/ \%$ of movements ${ }^{a}$} \\
\hline & $\begin{array}{c}\text { Aircraft } \\
\text { movements }^{\mathrm{a}}\end{array}$ & $\begin{array}{l}\text { Strikes } \\
\leq \mathbf{5 0 0} \text { feet }\end{array}$ & $\begin{array}{l}\text { Strikes } \\
>500 \text { feet }\end{array}$ & $\begin{array}{l}\text { Total } \\
\text { strikes }\end{array}$ & $\begin{array}{l}\text { Strikes } \\
\leq \mathbf{5 0 0} \text { feet }\end{array}$ & $\begin{array}{l}\text { Strikes } \\
>500 \text { feet }\end{array}$ & $\begin{array}{l}\text { Total } \\
\text { strikes }\end{array}$ \\
\hline Night & 18.2 & 15.6 & 60.8 & 28.1 & 0.86 & 3.34 & 1.54 \\
\hline Day & 81.8 & 84.4 & 39.2 & 71.9 & 1.03 & 0.48 & 0.88 \\
\hline Total & & 22,612 & 8,609 & 31,221 & & & \\
\hline Ratio: night/day & 0.22 & 0.19 & 1.55 & 0.39 & $0.83^{b}$ & $6.96^{c}$ & $1.75^{\mathrm{d}}$ \\
\hline
\end{tabular}

${ }^{a}$ The proportion of aircraft movements during night and day is based on data from Transport Canada for 1995-2003 (see Methods). Night movements annually ranged from $16.7-19.7 \%$ (mean $18.2 \%$ ) of total movements $(40,744,109)$ for the 9 -yr period.

$\mathrm{b}$ The proportion of strikes at $\leq 500$ feet during night and day was different $\left(\chi^{2}=99.0,1 \mathrm{df}, P=<0.001\right)$ than expected, based on the proportion of movements during night and day.

${ }^{c}$ The proportion of strikes at $>500$ feet during night and day was different $\left(\chi^{2}=10,469.7,1 \mathrm{df}, P<0.001\right)$ than expected, based on the proportion of movements during night and day.

${ }^{d}$ The proportion of total strikes during night and day was different $\left(\chi^{2}=2,048.6,1 \mathrm{df}, P<0.001\right)$ than expected, based on the proportion of movements during night and day. 
and monitor bird movements using bird-avoidance models (Lovell and Dolbeer 1999, Kelly et al. 2000) and birddetecting radar (Ruhe 2000, Bell 2003, Gauthreaux and Belser 2003). Based on my findings, these efforts need to focus on heights below 3,500 feet, with special emphasis on movements of birds at night during periods of migration, especially April-May and September-November. Furthermore, the exponential reduction by $32 \%$ of the mean probability for a bird strike for every 1,000 -foot increase in height is a general rule that may be useful for planners of military low-level training flights (Lovell and Dolbeer 1999). For example, changing the height of a training flight from 1,500 feet to 3,500 feet would reduce the mean probability of a bird strike by $54 \%$.

Waterfowl were by far the most frequently struck species above 500 feet and especially above 3,500 feet. These species typically have large $(>1 \mathrm{~kg})$ body masses and migrate in flocks, making them particularly hazardous to aircraft traveling at higher speeds (Dolbeer and Eschenfelder 2002). Civil aviation authorities in the United States, Canada, and Mexico already have rules or proposed rules to restrict aircraft to indicated airspeeds of 250 knots $(463 \mathrm{~km} /$ $\mathrm{hr}$ ) or less below 10,000 feet, in part because of concerns about strikes with these larger bird species (Sowden and Kelly 2002, Eschenfelder 2005). Because of a fundamental relationship between energy (e), mass ( $\mathrm{m})$, and velocity (v) expressed in the equation $\mathrm{e}=0.5 \mathrm{mv}^{2}$, aircraft velocity is even more critical than bird mass in determining the energy imparted to an aircraft by a strike (Dolbeer and Eschenfelder 2002). To reduce the probability and severity of strikes with these larger species, pilots should minimize flight time and airspeed below 10,000 feet and especially below 3,500 feet at night during periods of migration by increasing the rate of climb on departure and delaying descent into these zones on arrival until necessary to descend to land. Increasing the rate of climb will result in a reduction in airspeed (Sowden and Kelly 2002), which is of critical importance.

I did not attempt to conduct comparative analyses by species of birds because identification to a species group

\section{Literature Cited}

Allan, J. R., and A. P. Orosz. 2001. The costs of bird strikes to commercial aviation. Pages 218-226 in Bird strike 2001. Proceedings of the Bird Strike Committee-USA/Canada meeting. Transport Canada, Ottawa, Ontario, Canada.

Alerstam, T. 1990. Bird migration. Cambridge University, New York, New York, USA.

Bell, J. 2003. Improved bird movement studies using mobile radar. International Pest Control 45:20.

Bellrose, F. C. 1971. The distribution of nocturnal migrants in the air space. Auk 88:397-424.

Burger, J. 1985. Factors affecting bird strikes on aircraft at a coastal airport. Biological Conservation 33:1-28.

Cleary, E. C., and R. A. Dolbeer. 2005. Wildlife hazard management at airports, a manual for airport personnel. Second edition. U.S. Department of Transportation, Federal Aviation Administration, Office of Airport Safety and Standards, Washington, D.C., USA. <http:// wildlife-mitigation.tc.faa.gov>. Accessed 2006 Apr 21.

Cleary, E. C., R. A. Dolbeer, and S. E. Wright. 2005. Wildlife strikes to civil aircraft in the United States, 1990-2004. U.S. Department of occurred in only about $23 \%$ of the bird strikes above 500 feet. As improvements in the identification of struck species through feather and DNA analysis occur (Hermans et al. 1996, Dove 1997, Hebert et al. 2003) and as sample sizes increase with additional years of bird-strike data, comparisons of height distributions by various species and species groups of birds should be possible.

\section{Management Implications}

Management programs to reduce bird strikes with civil aircraft should focus on the airport environment because $66 \%$ of strikes causing substantial damage to aircraft occurred at $\leq 500$ feet. Daylight hours during the months of July-October, especially August, had the highest strike rates below 500 feet. Outside the airport environment, the height zone from 500 feet to 3,500 feet is the most hazardous, especially at night. Because strikes decline exponentially by $32 \%$ per 1,000 -foot increase in height above 500 feet, military planners can substantially reduce the mean probability of bird strikes by increasing the height of training flights. A 2,000-foot increase in height (e.g., from 1,500 feet to 3,500 feet) translates to a $54 \%$ reduction in the mean probability of a strike. Pilots of civil transport aircraft should minimize flight time and airspeed during climb and descent flight phases below 10,000 feet and especially below 3,500 feet at night during periods of migration to reduce the probability and severity of strikes.

\section{Acknowledgments}

The FAA, William Hughes Technical Center, Atlantic City, New Jersey, USA, under agreement DFTACT-03-X90031 supported this research. Opinions expressed in this study do not necessarily reflect current FAA policy decisions regarding the control of wildlife on or near airports. I appreciate the support and advice of S. Agrawal, E. C. Cleary, M. Hoven, and J. Lott (FAA); R. C. Beason and S. E. Wright (United States Department of Agriculture); B. T. MacKinnon and M. Villeneuve (Transport Canada); T. C. Kelly (National University of Ireland, Cork); and P. Eschenfelder (Avion Corporation).

Transportation, Federal Aviation Administration, Serial Report No. 11 DOT/FAA/AS/00-6(AAS-310), Washington, D.C., USA. <http:// wildlife-mitigation.tc.faa.gov>. Accessed 2006 Apr 21.

Dolbeer, R. A. 1998. Population dynamics: the foundation of wildlife damage management for the 21st century. Pages 2-11 in R. O. Baker and C. Crabb, editors. Proceedings of the 18th Vertebrate Pest Conference. University of California, Davis, USA.

Dolbeer, R. A., and P. Eschenfelder. 2002. Population increases of large birds, airworthiness standards, and high-speed flight: a precarious combination. Pages 273-281 in Proceedings of the 55th International Air Safety Seminar, Dublin, Ireland. Flight Safety Foundation, Alexandria, Virginia, USA.

Dolbeer, R. A., S. E. Wright, and E. C. Cleary. 2000. Ranking the hazard level of wildlife species to aviation. Wildlife Society Bulletin 28:372378.

Dove, C. J. 1997. Quantification of microscopic feather characters used in the identification of North American plovers. Condor 99:47-57.

Eschenfelder, P. 2005. High-speed flight at low altitude: hazard to commercial aviation? Proceedings of the Bird Strike Committee-USA 
Canada meeting. Transport Canada, Ottawa, Ontario, Canada. $<$ http://www.birdstrikecanada.com>. Accessed 2006 Apr 21.

Federal Aviation Administration. 2005. Aircraft movements and passenger enplanements. Federal Aviation Administration, Washington, D.C., USA. <http://www.apo.data.faa.gov>. Accessed 2005 Jul 5.

Gauthreaux, S. A., Jr., and C. G. Belser. 2003. Radar ornithology and biological conservation. Auk 120:266-277.

Hebert, P. D. N., A. Cywinska, S. L. Ball, and J. R. deWaard. 2003. Biological identification through DNA barcodes. Proceedings of the Royal Society of London B(2003) 270:313-321.

Hermans, J., L. S. Buurma, and J. Wattel. 1996. Identification of bird remains after bird-airplane collisions, based on DNA sequence analysis. Pages 203-207 in Proceedings of the 23rd Bird Strike Committee Europe meeting. Bird Strike Committee Europe, 13-17 May 1996, London, United Kingdom.

International Civil Aviation Organization. 1989. Manual on the ICAO Bird Strike Information System (IBIS). Third edition. International Civil Aviation Organization, Montreal, Quebec, Canada.

Kelly, T. A., R. Merritt, R. White, A. Smith, and M. Howera. 2000. The Avian Hazard Advisory System (AHAS): operational use of weather radar for reducing the bird strike risk in North America. Pages 166173 in J. Nugteren, editor. Proceedings of 25th International Bird Strike Committee meeting. Volume 2. International Bird Strike Committee, 17-20 April 2000, Amsterdam, Netherlands.

Kelly, T. C., M. J. A. O'Callaghan, and R. Bolger. 2001. The avoidance behaviour shown by the rook (Corvus frugilegus) to commercial aircraft. Pages 291-299 in H. J. Pelz, D. P. Cowan, and C. J. Feare, editors. Advances in vertebrate pest management II. Filander Verlag, Fürth, Germany.

Laybourne, R. C. 1974. Collision between a vulture and an aircraft at an altitude of 37,000 feet. Wilson Bulletin 86:461-462.
Lovell, C. D., and R. A. Dolbeer. 1999. Validation of the U.S. Air Force bird avoidance model. Wildlife Society Bulletin 27:167-171.

MacKinnon, B., editor. 2002. Wildlife control procedures manual. Transport Canada, Aerodrome Safety Branch, Publication TP 11500E, Ottawa, Ontario, Canada.

Richardson, W. J., and T. West. 2000. Serious birdstrike accidents to military aircraft: updated list and summary. Pages 67-98 in J. Nugteren, editor. Proceedings of 25th International Bird Strike Committee meeting. Volume 1. International Bird Strike Committee, 17-20 April 2000, Amsterdam, Netherlands.

Ruhe, W. 2000. ASR - Bird observation program at German airports. Pages 157-165 in J. Nugteren, editor. Proceedings of 25th International Bird Strike Committee meeting. Volume 2. International Bird Strike Committee, 17-20 April 2000, Amsterdam, Netherlands.

Sowden, R., and T. Kelly. 2002. Risk analysis of high-speed aircraft departures below 10,000 feet. Transport Canada, Aerodrome Safety Branch, Ottawa, Ontario, Canada.

Statistix. 2003. Statistix 8 user's manual. Analytical Software, Tallahassee, Florida, USA.

Thorpe, J. 2003. Fatalities and destroyed aircraft due to bird strikes, 1912-2002. Pages 85-113 in Proceedings of the 26th International Bird Strike Committee meeting. International Bird Strike Committee, 5-9 May 2003, Warsaw, Poland.

Thorpe, J. 2005. Fatalities and destroyed aircraft due to bird strikes, 2002-2004 (with an appendix of animal strikes). Pages 17-24 in Proceedings of the 27th International Bird Strike Committee meeting. Volume 1. International Bird Strike Committee, 23-25 May 2005, Athens, Greece.

Associate Editor: Ransom. 